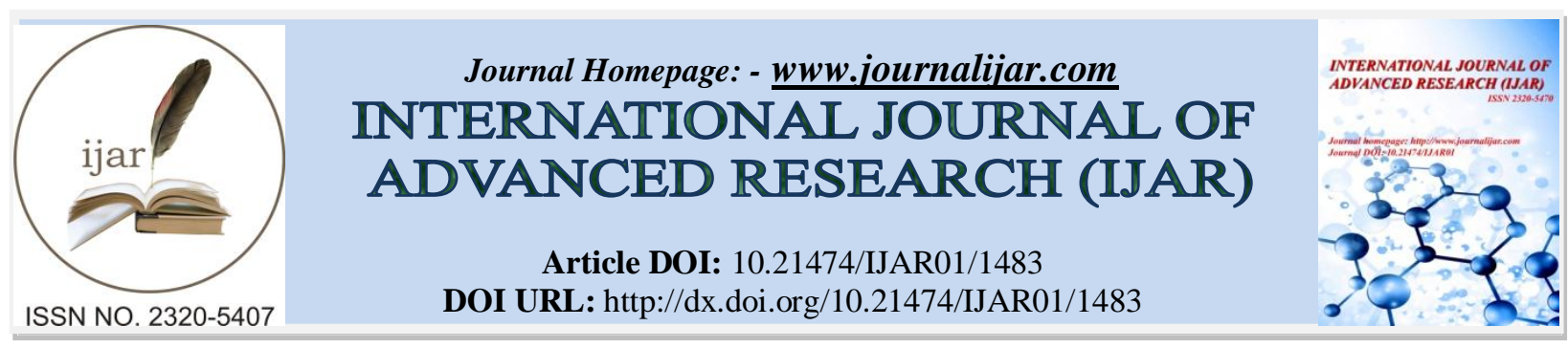

RESEARCH ARTICLE

\title{
KNOWLEDGE OF STUDENTS OF QASSIM UNIVERSITY REGARDING COLON CANCER.
}

\author{
Sima Mohammad AL Assaf, Saja Mohammad AL Assaf. and Arwa Alomar \\ Qassim College Of Medicine 2013-2014.
}

Manuscript Info

Manuscript History

Received: 16 July 2016

Final Accepted: 22 August 2016

Published: September 2016

\section{Abstract}

The crude frequency of colorectal cancer (CRC) is second to breast cancer in the Kingdom of Saudi Arabia (KSA)

In the year 2002, colorectal cancer (CRC) was the third and fourth most common cancer in females and males, respectively, worldwide.[1] Its prevalence is second only to that of breast cancer, with an estimated 2.8 million persons alive with CRC within five years of diagnosis. The highest incidence rates occurred in North America, Australia, Western Europe and Japan. The incidence tends to be low in Africa and Asia and intermediate in the southern parts of South America. Although the Kingdom of Saudi Arabia (KSA) is considered a low-incidence area for CRC, the disease ranks second, after breast cancer, constituting almost nine percent of the newly diagnosed cases, ranking first and third among the male and female population, respectively.[2]

Changing trends in the incidence and mortality of CRC have been shown in many high- and low-rate areas. The incidence rates of CRC are increasing rather rapidly in countries where the overall risk was formerly low.[13] For mortality, the pattern is similar, with an increase in the countries with a low initial rate, small increases or stable rates in countries with moderate rates, and a decrease for highrate populations.[13-15]

Copy Right, IJAR, 2016,. All rights reserved.

\section{Introduction:-}

The Kingdom of Saudi Arabia has experienced unprecedented economic and social development in recent decades, with increased per capita availability of oils and fats (200\%), animal fat (171\%), animal protein (207\%), meat (313\%), milk (120\%), eggs (648\%) and sugar (168\%), along with increased consumption of calories and proteins by individuals, which exceeds the recommended daily allowances by 147 and $217 \%$, respectively.[32,33] On the flip side, only $40 \%$ of Saudis eat fresh vegetables or fruits daily.[34] A national cross-sectional study showed that only $28 \%$ of adult Saudis do physical exercise three times a week. Among the Saudis, $35 \%$ are obese and $37 \%$ are overweight.[34]

Since the estimated induction/latency period for CRC may be quite long, [35] low ASRs for CRC in KSA, in the early 1990's, probably reflected the low level of exposure to environmental risk factors in the preceding two or three decades. Thereafter, rapid and progressive rising rates reflect the fast acquisition of western lifestyle, which may be associated with the financial spike all over the country. Ranked fifth among the incidences of cancer in KSA in 
1994, CRC became the second, after breast cancer, in 2003. In Saudis as well as non-Saudis, CRC is the first and third cancer in males and females, respectively.

The screening of average risk individuals (aged 50 and older) for colorectal cancer through use of the fecal occult blood test in conjunction with sigmoidoscopy can increase the likelihood of early detection of this disease. This practice, coupled with prompt diagnostic work-up following positive tests, will result in treatment of earlier stage cancers and increased survival after treatment. [J Natl Cancer Inst 85:1311-1318, 1993]

Objectives:-

To assess the knowledge of students from college of computer sciences regarding cancer colon.

\section{General Objectives:-}

To assess the knowledge of students from college of computer sciences regarding cancer colon.

\section{Secondary Objectives:-}

To assess the knowledge of students from college of computer sciences regarding the risk factors of cancer colon.

\section{Methodology:-}

After explaining the objectives of the study and taking verbal consent; a pre-designed, pre-tested,structured questionnaire was distributed among randomly selected one hundred female students from college of computer sciences. the filled questionnaire was collected in the same session.

Study design and setting:-

Across sectional study was conducted among female students from college of computer sciences Qassim university.

\section{Study population:-}

Female students from college of computer sciences Qassim university.

\section{Inclusion criteria:}

Randomly selected students willing to participate in the study.

\section{Exclusion criteria:-}

Students not willing to participate in the study.

\section{Sample type:-}

Simple random sampling

\section{Sample size:-}

A total of hundred students were selected from college of computer sciences Qassim university.

\section{Data collection:-}

Data was collected; Through a pre-designed, pre-tested, structured questionnaire.

\section{Data Analysis:-}

Data was analyzed using software statistical Package of Social Science (SPSS 15) for window- Evaluation version.

\section{Ethical Review:-}

- The aims of the research was explained to the participants.

- Participants were assured that their responses to the questionnaires will be anonymous and confidential.

- Participation was voluntary and under no obligation.

- Verbal consent was also taken before data collection. 


\section{Results:-}

A total of one hundred female students from college of computer sciences Qassim University participated in the study.

In response to the question regarding which age group is most commonly affected by cancer colon; $43 \%$ responded that persons over fifty years of age are more commonly affected, while $28 \%$ replied that persons below the age of fifty are commonly affected, $29 \%$ of the students did not know the answer.

Quite a good no of the students $71 \%$ think that smoking is a risk factor for cancer colon, while $11 \%$ think smoking has no role in cancer colon and $18 \%$ do not have any idea about this.

In response to the question regarding unhealthy diet; $65 \%$ of the students replied 'yes', while many of the students $24 \%$ replied with 'I do not know' and $11 \%$ said that unhealthy diet is not a risk factor for colon cancer.

Regarding the question fiber intake and cancer colon; $52 \%$ of the students responded as 'yes' increase fiber intake can reduce the risk for having colon cancer, while a big number $40 \%$ did not know about this and rest $8 \%$ think that increasing fiber intake in the diet does not decrease the risk of having cancer colon.

Responding to a question that physical activity can decrease the risk of cancer colon; $62 \%$ of the students think that physically active people have less risk of having cancer colon, while $13 \%$ replied that physical activity do not reduce the risk for cancer colon and $25 \%$ have no idea about this relationship.

\section{2-do you think colon polyps has role in colon cancer}

\begin{tabular}{|l|l|l|l|l|l|}
\hline \multicolumn{2}{|l|}{ Valid } & Frequency & Percent & Valid Percent & Cumulative Percent \\
\cline { 2 - 6 } & yes & 34 & 34.0 & 34.0 & 34.0 \\
\cline { 2 - 6 } & no & 15 & 15.0 & 15.0 & 49.0 \\
\cline { 2 - 6 } & Total know & 51 & 51.0 & 51.0 & 100.0 \\
\cline { 2 - 6 } & Total & 100 & 100.0 & 100.0 & \\
\hline
\end{tabular}

Do you think who has family history of colon cancer has risk factor for it

\begin{tabular}{|l|l|l|l|l|l|}
\hline \multicolumn{2}{|c|}{} & Frequency & Percent & Valid Percent & Cumulative Percent \\
\hline \multirow{7}{*}{ Valid } & yes & 53 & 53.0 & 53.0 & 53.0 \\
\cline { 2 - 6 } & no & 26 & 26.0 & 26.0 & 79.0 \\
\cline { 2 - 6 } & idont know & 21 & 21.0 & 21.0 & 100.0 \\
\cline { 2 - 6 } & Total & 100 & 100.0 & 100.0 & \\
\hline
\end{tabular}

Do you think who recover of colon cancer can be affected again

\begin{tabular}{|l|l|l|l|l|l|}
\hline \multicolumn{2}{|c|}{} & Frequency & Percent & Valid Percent & Cumulative Percent \\
\hline Valid & yes & 52 & 52.0 & 52.0 & 52.0 \\
\cline { 2 - 6 } & no & 20 & 20.0 & 20.0 & 72.0 \\
\cline { 2 - 6 } & idont know & 28 & 28.0 & 28.0 & 100.0 \\
\cline { 2 - 6 } & Total & 100 & 100.0 & 100.0 & \\
\hline
\end{tabular}

Do you think women who has ovarian or uterine cancer has risk factor for colon cancer

\begin{tabular}{|l|l|l|l|l|l|}
\hline \multicolumn{2}{|c|}{} & Frequency & Percent & Valid Percent & Cumulative Percent \\
\hline Valid & yes & 22 & 22.0 & 22.0 & 22.0 \\
\cline { 2 - 6 } & no & 30 & 30.0 & 30.0 & 52.0 \\
\cline { 2 - 6 } & i dont know & 48 & 48.0 & 48.0 & 100.0 \\
\cline { 2 - 6 } & Total & 100 & 100.0 & 100.0 & \\
\hline
\end{tabular}


Do you think women who has breast cancer has risk factor of colon cancer.

\begin{tabular}{|c|c|c|c|c|c|}
\hline & Frequency & Percent & Valid Percent & Cumulative Percent \\
\hline \multirow[t]{4}{*}{ Valid } & yes & 26 & 26.0 & 26.0 & 26.0 \\
\hline & no & 38 & 38.0 & 38.0 & 64.0 \\
\hline & i dont know & 36 & 36.0 & 36.0 & 100.0 \\
\hline & Total & 100 & 100.0 & 100.0 & \\
\hline
\end{tabular}

Do you think unhealthy diet (increase cholesterol )has risk factor of colon cancer

\begin{tabular}{|l|l|l|l|l|l|}
\hline \multicolumn{2}{|c|}{} & Frequency & Percent & Valid Percent & Cumulative Percent \\
\hline \multirow{5}{*}{ Valid } & yes & 65 & 65.0 & 65.0 & 65.0 \\
\cline { 2 - 6 } & no & 11 & 11.0 & 11.0 & 76.0 \\
\cline { 2 - 6 } & i dont know & 24 & 24.0 & 24.0 & 100.0 \\
\cline { 2 - 6 } & Total & 100 & 100.0 & 100.0 & \\
\hline
\end{tabular}

\section{Discussion:-}

The study was conducted to assess the knowledge of non medical female students of Qassim University.

It was observed that quite a good percentage of the students do not have an idea regarding the age group most commonly affected by the cancer colon, while the students having wrong knowledge about this are also not low.

Regarding the knowledge about the risk factors for cancer colon; it was noted that although a good percentage have moderate level of correct information, still a reasonable percentage of the students either do not know about many of the risk factors for cancer colon or they are unaware about the important risk factors for this disease.

\section{Conclusion:-}

There is much deficiency found among the non medical students of Qassim University regarding the knowledge about cancer colon especially the risk factors.

\section{Recommendations:-}

There should be some educational activities in non medical colleges of Qassim University to create awareness regarding the knowledge of important health problems.

More studies are needed at a larger scale involving male students and other colleges.

\section{Limitations:-}

- The study was conducted among female students from Computer College only.

- Sample size was also small.

Work Plan:-

\begin{tabular}{|l|l|l|l|l|l|l|}
\hline Task & $\mathbf{1}$ & $\mathbf{2}$ & $\mathbf{3}$ & $\mathbf{4}$ & $\mathbf{5}$ & $\mathbf{6}$ \\
\hline Proposal & $\mathrm{X}$ & $\mathrm{X}$ & & & & \\
\hline Data collection & & & $\mathrm{x}$ & $\mathrm{X}$ & & \\
\hline Data entry & & & & $\mathrm{X}$ & $\mathrm{X}$ & \\
\hline Data analysis & & & & & $\mathrm{X}$ & \\
\hline Report writing & & & & & & $\mathrm{X}$ \\
\hline
\end{tabular}

Budget:-

\begin{tabular}{|l|l|l|l|}
\hline Category & Unit cost & Number & Total \\
\hline & & & \\
\hline Questionnaire & 5 & 100 & 500 \\
\hline Report & 5 & 100 & 500 \\
\hline Grand total & & 1000 SR \\
\hline
\end{tabular}




\section{References:-}

1. Swan J, Breen N, Coates RJ, Rimer BK, Lee NC. Progress in cancer screening practices in the United States: Results from the 2000 National Health Interview Survey. Cancer. 2003;97:1528-40.[PubMed]

2. Robertson RH, Burkhardt JH, Powell MP, Eloubeidi MA, Pisu M, Weissman NW. Trends in colon cancer screening procedures in the US Medicare and Tricare populations: 1999-2001. Prev Med. 2006;42:4602.[PubMed]

3. Vogelaar I, van Ballegooijen M, Schrag D, Boer R, Winawer SJ, Habbema JD, et al. How much can current interventions reduce colorectal cancer mortality in the US? Mortality projections for scenarios of risk-factor modification, screening, and treatment. Cancer. 2006;107:1624-33.[PubMed]

4. Mandel JS, Bond JH, Church TR, Snover DC, Bradley GM, Schuman LM, et al. Reducing mortality from colorectal cancer by screening for fecal occult blood: Minnesota Colon Cancer Control Study. N Engl J Med. 1993;328:1365-71.[PubMed]

5. Khan MA, Al-Kanhal MA. Dietary energy and protein requirements for Saudi Arabia: A methodological approach. East Mediterranean Health J. 1998;4:68-75.

6. King Abdul Aziz City for Science and Technology. Riyadh, Saudi Arabia: 1995. Evaluation of the nutritional status of the people of Saudi Arabia 